\title{
Algerina gen. nov. (Bivalvia, Nepiomorphia) from the Silurian of the North Gondwana margin (Algeria), peri-Gondwanan Europe (France, Italy), Perunica (Prague Basin, Bohemia) and the Siberian Plate (Tajmyr Basin, Russia)
}

JIŘí KŘíž

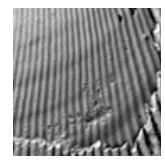

\begin{abstract}
Algerina gen. nov. (Bivalvia, Spanilidae Kř̌̌ž, 2007), with its type species Algerina algena sp. nov., is described from the Silurian (lower Ludlow) of Algeria, western Hoggar Mountains, Ahnet Massif and the Ougarta Range. The new genus is also known from the upper Wenlock of France, the Montagne Noire [Algerina chaubetae (Kř́rž, 1996)], and from the lower Ludlow of Italy, the Carnic Alps [Algerina cocco (Kř́̌̌z, 1999)]. Algerina rebellis (Barrande, 1881) is known from the lower Ludlow and Algerina faba (Barrande, 1881) from the middle Ludlow of Bohemia, Prague Basin. Algerina faba is also known from the lower Ludlow of the Tajmyr Basin, Russia. $\bullet$ Key words: Bivalvia, Nepiomorphia, new taxa, Silurian, Algeria, France, Italy, Bohemia, Tajmyr (Russia).
\end{abstract}

Ǩ̌íž, J. 2008. Algerina gen. nov. (Bivalvia, Nepiomorphia) from the Silurian of the North Gondwana margin (Algeria), peri-Gondwanan Europe (France, Italy), Perunica (Prague Basin, Bohemia) and the Siberian Plate (Tajmyr Basin, Russia). Bulletin of Geosciences 83(1), 79-84 (1 figure). Czech Geological Survey, Prague. ISSN 1214-1119. Manuscript received November 11, 2007; accepted in revised form December 11, 2007; issued March 31, 2008.

Jiři Kř̌žz, Czech Geological Survey, Klárov 3, P.O. Box 85, 11821 Praha 1, Czech Republic; jiri.kriz@geology.cz.

Patrick Racheboeuf from the Université Claude Bernard, Centre des Sciences de la Terre, Villeurbane, France, discovered in 2004 and 2005 abundant bivalves in the Silurian cephalopod limestone levels at the Foum Belrem section in the Ahnet Massif, western Hoggar Mountains and at the Oved Ali Section in the Ougarta Range, Algeria. The field collection of bivalves and about 5 kilograms of cephalopod limestone were sent to the author in 2005 and 2006. Bivalves collected from the samples by the author in the laboratory, together with the field collections, were sufficient to make a community analysis and to correlate the cephalopod limestone levels with horizons in the Prague Basin, Bohemia. A new genus Algerina gen. nov. was discovered, representing the ancestral form of the Spanilidae Kř́ž, 2007, Nepiomorphia Kř́ž 2007 (Bivalvia). Here the taxonomy of the new genus and species and reassignment of several other taxa is presented.

\section{Systematic palaeontology}

Abbreviations. - JK 11472-JK 11498 - specimens studied and deposited in the collection of Jiří Křiž in the Czech Geological Survey, Prague, Bohemia. NM L 7011, and
NM L 22815 - specimens deposited in the National Museum, Prague, Bohemia; DSTL 340 198, and DSTL 340 181 - specimens deposited in the collections of the Département des Sciences de la Terre, Lyon, France; GBA 4946 - specimen deposited in the collections of the Geologische Bundesanstalt, Vienna, Austria.

Class Bivalvia Linné, 1758

Superordo Nepiomorphia Kříž, 2007

Order Antipleuroida Křižz, 2007

Superfamily Antipleuroidea Kř̌̌ž, 2007

Family Spanilidae Kříž, 2007

\section{Genus Algerina gen. nov.}

Type species. - Algerina algena sp. nov.

Derivation of name. - Derived from geographic name Algeria. Gender feminine.

Diagnosis. - Relatively large spanilid, almost equivalved, inequilateral, obese, prosocline to opisthocline, enantiomorphous (most of shells inclined to the left). Commissure lies within a single plane. Bulky prosogyrate umbones in 
central position or slightly shifted posteriorly. Shell is thin, obliquely broadly elliptical in outline and obese. Frontal face is widely lanceolate, slightly inflated, steeper than posterior part of the shell and separated from the central part of the shell by a band, prominent in umbonal part. Posterior part with wing-like shape, separated from the central part of the shell by a shallow radial sulcus. Inner and outer surface sculpture formed by numerous prominent, narrow radial ribs and gutters broadening ventrally and curved anteriorly. Outer surface sculpture on the frontal face is generally smoother. Distinct growth sculptures developed in early ontogenetic stages as growth bands of variable width and convexity, and narrow growth furrows. Area is low, triangular. Hinge line straight, much shorter than the length of the shell, with small peg-like pseudotaxodont teeth. Relatively large, widely elliptical posterior adductor scar is developed close to the shell margin, posteriorly of the radial sulcus.

Remarks. - The upper Silurian Algerina gen. nov. is most probably ancestral to Spanilidae Kříž, 2007. By its general shape Algerina is related to Tetinka cuneus (Barrande, 1881), the earliest species of the Tetinka cuneus - Tetinka trigona (Münster in Goldfuss, 1837) - Tetinka accedens (Barrande, 1881) - Tetinka sagitta (Barrande, 1881) - Tetinka elongata Barrande, 1881 lineage. Algerina differs from the genus Tetinka by its larger, widely elliptical and distinctly inflated shells with bulky umbones. For both genera enantiomorphous shells (Kříž 2001) are characteristic. Shells in Algerina are inclined to the left whereas to the right in Tetinka. Enantiomorphous dimorphism in the Spanilidae is suppressed and is reflected in the shells reclining to the left or to the right in different species and genera.

Barrande (1881) figured from the Prague Basin Dualina concentrica Barrande, 1881 ( $\mathrm{Pl} .293$, figs 15-18) from the upper Přídolí and Dualina consors Barrande, 1881 (Pl. 20, figs 15-17) from the lower Lochkovian (Lower Devonian). These species have similar growth bands in the umbonal part, and a similar general morphology to Algerina but they differ in the commissure, which lies not within a single plane but is curved laterally toward the opposite valve, as in Sibirinka Bogolepova \& Kř́iž, 1995,
Dualina Barrande, 1881, and Antipleura Barrande, 1881. Dualina concentrica and Dualina consors probably represent an adaptive convergence of some representatives of Dualina (Antipleuridae) and Algerina (Spanilidae) in a similar environment to the cephalopod limestone biofacies in the late Př́idolí (Silurian) and early Lochkovian (Lower Devonian).

Species and distribution. - Algerina algena sp. nov., lower Ludlow, Gorstian of Algeria, western Hoggar Mountains, Ahnet Massif and the Ougarta Range; Algerina chaubetae (Křiž, 1996), upper Wenlock of France, the Montagne Noire (Kř́̌ž 1996); Algerina cocco (Křǐž, 1999), lower Ludlow of Italy, the Carnic Alps (Kříž 1999); Algerina rebellis (Barrande, 1881), lower Ludlow of Bohemia, the Prague Basin; Algerina faba (Barrande, 1881), middle Ludlow of Bohemia, the Prague Basin, and lower Ludlow of Russia, Tajmyr (Kř́̌ž \& Bogolepova 1995).

\section{Algerina algena sp. nov.}

Figure 1A-M, O-R, U, V, Z

Holotype. - Internal mould of the left valve with fragments of shell JK 11492, figured in Fig. 1Z, with counterpart JK 11493.

Paratypes. - JK 11472 - JK 11491, JK 11494 - JK 11498, measured for dimensions and figured in Fig. 1A-M, O-R, $\mathrm{U}, \mathrm{V}$.

Derivation of name. - Name derived from Algeria; indeclinable noun.

Type locality. - Algeria, northern margin of the western Hoggar Mountains, Ahnet Massif, Foum Belrem Section, Coord.: $25^{\circ} 56^{\prime} 92^{\prime \prime} \mathrm{N}$; $03^{\circ} 14^{\prime} 01^{\prime \prime} \mathrm{E}$.

Type horizon. - Silurian, Ludlow, lower Gorstian, most probably Colonograptus colonus Biozone.

Material. - 11 left, 14 right valves, 1 shell with conjoi-

Figure 1. A-M, O-R, U-V, Z-Algerina algena gen. nov., sp. nov., Ludlow, lower Gorstian, Algeria, northern margin of the western Hoggar Mountains, Ahnet Massif, Foum Belrem Section. • A - right lateral view, JK 11491, Stage II and III, x 9. • B-E - articulated specimen, right valve, JK 11472. - B - lateral view, Stage II and III, x 3.7. • C - lateral view, x 3.6. $\bullet$ D - ventral view, x 3.5. • E - anterior view, x 3.7. $\bullet$ F - right lateral view, JK 11476 , x 2.7. $\bullet \mathrm{G}, \mathrm{M}$ - right valve, JK $11498 . \bullet \mathrm{G}$ - dorso-lateral view, x 5.3. $\bullet \mathrm{M}$ - lateral view, x 5.3. $\bullet$ H-J - left valve, JK 11477 . $\bullet$ H - postero-lateral view, x 2.5.

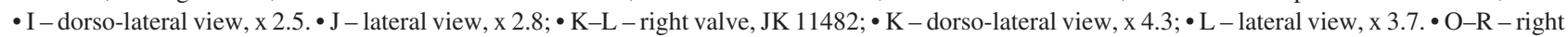
valve, JK $11485 . \bullet \mathrm{O}$ - antero-lateral view, $\mathrm{x}$ 4.2. $\bullet \mathrm{P}$ - dorso-lateral view, x 4.7. $\bullet \mathrm{R}$ - lateral view, x 4.3. $\bullet \mathrm{U}-\mathrm{V}-$ left valve, JK 11494 . $\bullet \mathrm{U}-$ internal mould of hinge area with pseudotaxodont teeth, x 9.・V - lateral view, x 6.6. $\bullet \mathrm{Z}$ - left lateral view, JK 11492, holotype, x 3.9. $・ \mathrm{~N}-$ Algerina faba $($ Barrande, 1881), middle Ludlow, Dvorce, Prague Basin, Bohemia, NM L 7011, holotype, left lateral view, x 4.7. • S, Y - Algerina chaubetae (Křǐž, 1996), Wenlock, Homerian, Roquemaillére, the Montagne Noire, France. • S - left lateral view, DSTL 340 198, holotype, x 3.9. • Y - right lateral view, DSTL 340 181, x 3. • T - Algerina cocco (Křǐž, 1999), lower Ludlow, Mt Cocco, the Carnic Alps, Italy, GBA 4946, holotype, left lateral view, x 5.7. -X - Algerina rebellis (Barrande, 1881), lower Ludlow, Praha-Malá Chuchle, Prague Basin, Bohemia, NM L 22815, holotype, left lateral view, x 1.6. 


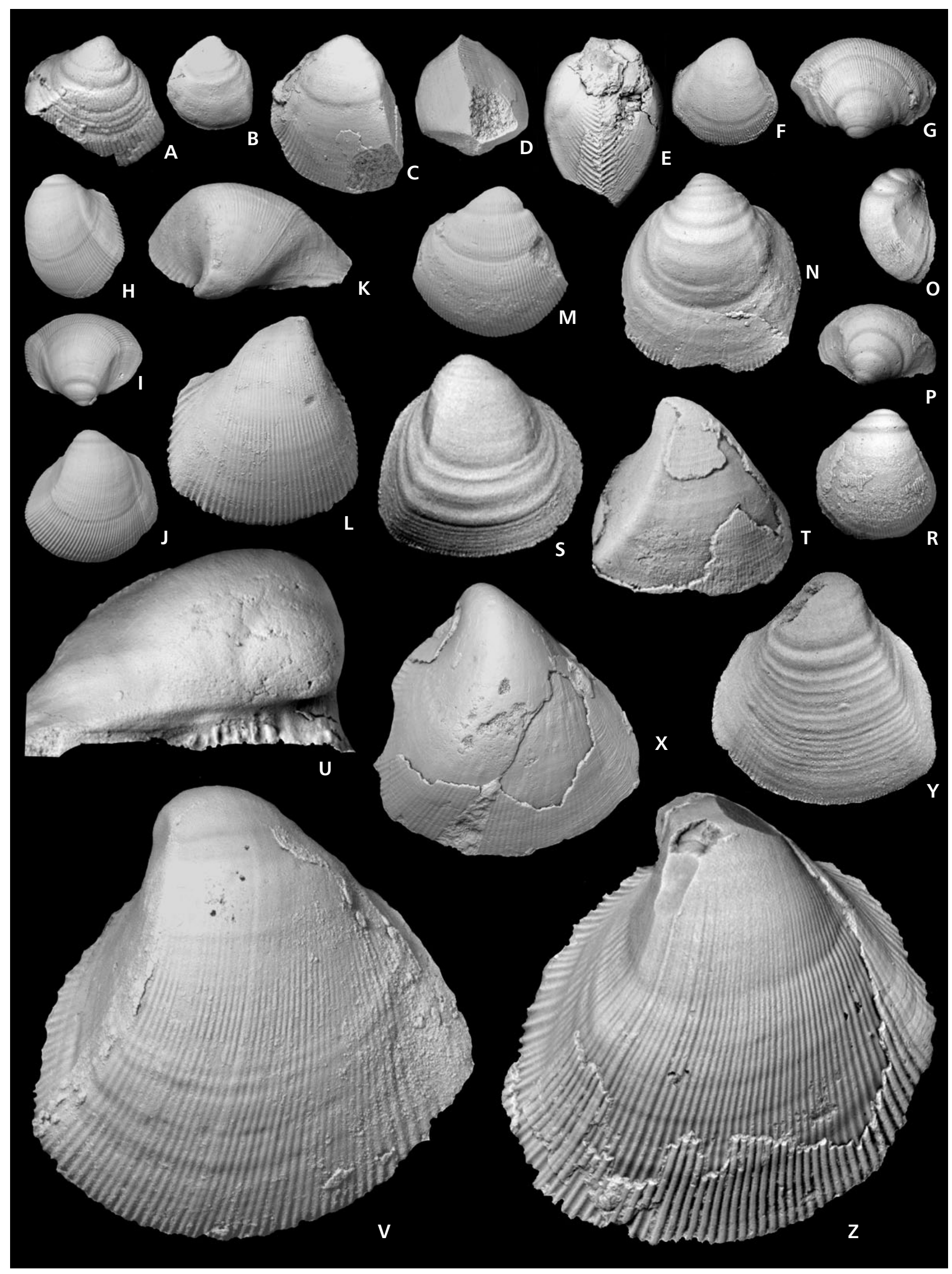


ned valves (JK 11472-JK 11498), fragments of 22 left, and 29 right valves from the Foum Belrem Section, Ahnet Massif. 12 left and 7 right valves from the Oued Ali Clay Formation, the Oued Ali Section, Ougarta Range, Algeria.

Diagnosis. - Opisthocline Algerina with bulky and coiled umbones.

Description. - Stage II (Kř̌iž 1979) - Shell subcircular in outline, moderately inflated, equivalved, inequilateral, slightly opisthocline. Commissure lies within a single plane. Beaks prosogyrate. Frontal face is steeper than posterior of the valve. Outer and inner surface sculpture formed by very fine radial ribs in combination with wide, flat, regularly spaced growth bands separated by shallow, growth furrows. Other features are unknown.

Stage III - Swollen band (Kříž 1979) wide. Shell broadly ovate, obese, almost equivalved, opisthocline, enantiomorphous, inclined to the left. Commissure lies within a single plane. Anterior slope of valve is much steeper than posterior slope. Anterior face of the valve separated from the central part of the valve by a distinct bend developed during early growth of Stage III. Outer and inner surface sculpture consists of fine, numerous radial ribs. Shell thickness is $0.03-0.1 \mathrm{~mm}$. Other features are unknown.

Stages IV and V - Shell broadly elliptical, obese ( $\mathrm{L} / \mathrm{W}=0.94-1.31, \mathrm{H} / \mathrm{W}=0.95-1.35)$, almost equivalved, inequilateral, opisthocline, enantiomorphous, inclined to the left. Commissure is posteriorly slightly curved toward the left valve. Bulky coiled umbones in central position or slightly shifted to posterior. Anterior slope of the valve with frontal face is steeper than posterior slope. Widely lanceolate, slightly inflated frontal face separated from the central part of the shell by bend, prominent in umbonal part, slightly curved anteriorly. Posterior part with wing-like shape, separated from the central part of the shell by a shallow radial sulcus. Inner and outer surface sculpture formed by anteriorly curved, prominent, narrow, radial ribs (in adult specimens 20-38 on frontal face, 43-50 in central part of the valve, 2-4 on the wing, and $9-12$ between the wing and the hinge line). Holotype JK 11492 has 35 radial ribs on frontal face, 47 in central part of the valve, 3-4 on the wing, and 12 between the wing and hinge line. Radial ribs and gutters equal in width, broadening ventrally. Outer surface sculpture of frontal face is generally smoother. Distinct growth sculptures developed in the umbonal part as regularly-spaced wide growth bands of variable convexity, and narrow growth furrows. Beak formed by early ontogenetic stages II and III. In Stage IV the convexity and width of growth bands decreases and in Stage $\mathrm{V}$ growth bands are missing. Area is low, triangular. Hinge line is straight, much shorter than the length of the shell. Irregular small, peg-like pseudotaxodont teeth developed, anteriorly increasing in size (Fig. 1U). A relatively large, widely elliptical posterior adductor scar is developed close to the shell margin, posteriorly of the radial sulcus. Shell thickness is $0.19-0.25 \mathrm{~mm}$.

Dimensions. - [V - valve ( $\mathrm{L}$ - left, $\mathrm{R}$ - right), $\mathrm{L}$ - length, $\mathrm{H}$ - height, width/2 - width of one valve (Křǐz 1969), L/W $\mathrm{L} / \mathrm{W}$ ratio, $\mathrm{H} / \mathrm{W}-\mathrm{H} / \mathrm{W}$ ratio. All measurements are in millimetres.]

\begin{tabular}{|c|c|c|c|c|c|c|c|}
\hline No. & $\mathrm{V}$ & $\mathrm{L}$ & $\mathrm{H}$ & width/2 & $\mathrm{L} / \mathrm{W}$ & $\mathrm{H} / \mathrm{W}$ & \\
\hline JK 11485 & $\mathrm{R}$ & 1.7 & 1.6 & 0.5 & 1.70 & 1.60 & (Stage II) \\
\hline JK 11491 & $\mathrm{R}$ & 2.2 & 1.9 & 0.6 & 1.83 & 1.58 & (Stage II) \\
\hline JK 11484 & $\mathrm{R}$ & 2.3 & 2.8 & 1.0 & 1.15 & 1.40 & (Stage III) \\
\hline JK 11485 & $\mathrm{R}$ & 2.4 & 2.3 & 1.1 & 1.09 & 1.04 & (Stage II) \\
\hline JK 11472 & $\mathrm{R}$ & 3.0 & 2.9 & 0.8 & 1.87 & 1.81 & (Stage II) \\
\hline JK 11485 & $\mathrm{R}$ & 3.1 & 3.0 & 0.9 & 1.94 & 1.67 & (Stage III) \\
\hline JK 11498 & $\mathrm{R}$ & 3.2 & 2.8 & 1.0 & 1.60 & 1.40 & (Stage II) \\
\hline JK 11472 & $\mathrm{R}$ & 3.9 & 4.2 & 1.4 & 1.39 & 1.50 & (Stage III) \\
\hline JK 11498 & $\mathrm{R}$ & 4.7 & 4.8 & 1.9 & 1.24 & 1.26 & (Stage III) \\
\hline JK 11485 & $\mathrm{R}$ & 4.9 & 5.4 & 2.5 & 0.98 & 1.08 & \\
\hline JK 11484 & $\mathrm{R}$ & 5.3 & 6.1 & 2.5 & 1.06 & 1.22 & \\
\hline JK 11498 & $\mathrm{R}$ & 5.5 & 5.3 & 2.9 & 0.94 & 0.91 & \\
\hline JK 11472 & $\mathrm{R}$ & 6.6 & 7.0 & 2.5 & 1.32 & 1.40 & \\
\hline JK 11486 & $\mathrm{~L}$ & 6.6 & 7.4 & 3.6 & 0.92 & 1.03 & \\
\hline JK 11476 & $\mathrm{R}$ & 7.3 & 7.1 & 2.9 & 1.26 & 1.22 & \\
\hline JK 11477 & $\mathrm{~L}$ & 8.8 & 8.8 & 4.0 & 1.10 & 1.10 & \\
\hline JK 11479 & $\mathrm{~L}$ & 8.8 & 10.0 & 4.4 & 1.00 & 1.14 & \\
\hline JK 11482 & $\mathrm{R}$ & 9.0 & 9.5 & 4.1 & 1.10 & 1.16 & \\
\hline JK 11487 & $\mathrm{R}$ & 10.0 & 10.9 & 4.6 & 1.09 & 1.18 & \\
\hline JK 11489 & $\mathrm{R}$ & 10.3 & 11.0 & 5.5 & 0.94 & 1.00 & \\
\hline JK 11481 & $\mathrm{~L}$ & 5.0 & 11.0 & 10.5 & 1.10 & 1.05 & \\
\hline JK 11478 & $\mathrm{~L}$ & 11.8 & 10.8 & 4.7 & 1.26 & 1.15 & \\
\hline JK 11494 & $\mathrm{~L}$ & 12.0 & 12.5 & 5.3 & 1.13 & 1.18 & \\
\hline JK 11475 & $\mathrm{~L}$ & 12.3 & 12.5 & 5.8 & 1.06 & 1.08 & \\
\hline JK 11490 & $\mathrm{R}$ & 12.9 & 13.0 & 5.5 & 1.17 & 1.18 & \\
\hline JK 11483 & $\mathrm{R}$ & 13.6 & 14.1 & 7.1 & 0.95 & 0.99 & \\
\hline JK 11497 & $\mathrm{~L}$ & 13.9 & 13.0 & 6.0 & 1.16 & 1.08 & \\
\hline JK 11473 & $\mathrm{R}$ & 14.7 & 14.9 & 6.9 & 1.07 & 1.08 & \\
\hline JK 11496 & $\mathrm{R}$ & 15.6 & 15.2 & 8.0 & 0.97 & 0.95 & \\
\hline JK 11497 & $\mathrm{R}$ & 15.6 & 15.3 & - & - & - & (Stage V) \\
\hline JK 11492 & $\mathrm{~L}$ & 20.5 & 21.0 & 7.8 & 1.31 & 1.35 & (Stage V) \\
\hline JK 11495 & $\mathrm{~L}$ & 22.0 & 20.8 & 8.5 & 1.29 & 1.22 & (Stage V) \\
\hline
\end{tabular}

Discussion. - Algerina chaubetae (Křǐž, 1996), described as Dualina? chaubetae sp. n. on p. 41-42, pl. 1, figs 1-8, 10, 11, occurs in the lower Homerian, Wenlock of France, 
Montagne Noire (Fig. 1S,Y). Algerina algena sp. nov. is known from the lower Gorstian, Ludlow of Algeria (Ougarta Range and Ahnet Massif). In the early Ludlow of the Carnic Alps, Italy, occurs Algerina cocco (Kř̌̌ž, 1999), described as Dualina? cocco sp. n. on pp. 268-270, pl. 2, figs 3, 4, 7-9, 11 (Fig. 1T). All three species have generally a similar shape. Shells of Algerina chaubetae have more numerous, finer radial ribs and the shells are slightly prosocline. Opisthocline shells are characteristic for Algerina cocco and Algerina algena. Algerina cocco differs from the type species by its higher shells, more numerous radial ribs, narrower, less coiled umbo, and well developed bend between anterior face and central part of the valve. In all known species of Algerina the ontogenetic stages II-IV are well developed and expressed by growth bands of different width. The swollen band represents Stage III and is prominent. Stage V is most probably expressed by numerous, narrow growth bands and furrows expressing the growth slow down of the shell.

In general shape and surface sculpture closely related to Algerina algena are enantiomorphous Algerina rebellis (Barrande, 1881) from the Prague Basin, Bohemia, Gorstian (Fig. 1X) figured by Barrande (1881) on Pl. 293, figs 9-12 (as Dualina rebellis Barr.) and Algerina faba (Barrande, 1881) (Fig. 1N) figured by Barrande on Pl. 167, figs IV/1-3 (as Cardiola faba Barr.). Algerina rebellis differs from Algerina algena mainly in its generally larger shells, narrower umbones, more numerous radial ribs and the shells more inclined to the left. Algerina faba differs mainly in its orthocline and less inflated shells.

Mode of life. - Enantiomorphous and mostly opisthocline shells with frontal face were most probably adapted to a byssate, reclining mode of life. Most probably the byssus, which projected as separate threads through the commissure between the lanceolate frontal faces as in Recent Hippopus hippopus (Linné, 1758), pulled the shell against the substrate and facilitated its penetration. The process stopped when the opposite margins of the valves, which must remain capable of opening, was almost flush with the surface of the sediment.

Occurrence. - Algeria, type locality and Ougarta Range, Saoura area, Oued Ali Section, Coord.: 29 41'39" N; $02^{\circ} 11^{\prime} 21^{\prime \prime} \mathrm{W}$ (25-cm thick lower cephalopod limestone bed intercalated in silty deposits of the Oued Ali Clay Formation).

\section{Conclusions}

Algerina gen. nov. is one of the archaic ancestral forms of the Nepiomorphia Kř́ž, 2007 characterized by obese, subcircular shell with large umbones, numerous radial ribs and simple pseudotaxodont hinge, which originated during the first major diversification of the family in the recurring cephalopod limestone biofacies (Kř́iž 1998) during the early Silurian in peri-Gondwana. Algerina gen. nov. shows enantiomorphous dimorphism (Kř́ž 2001), a unique character of the Silurian and most of the Devonian Antipleuroida Kříž, 2007. The genus represents most probably the oldest known ancestral form of the Spanilidae Kř́ž, 2007 and it is related to the oldest representative of the Antipleuridae Neumayr, 1891 Sibirinka Bogolepova \& Kříž, 1995 from the Rhuddanian of Siberia.

\section{Acknowledgements}

My special thanks are extended to Patrick Racheboeuf, Université Claude Bernard, Centre des Sciences de la Terre, URA $11 \mathrm{du}$ CNRS - Paléozoique, Villeurbanne, France, who kindly made available to me bivalves and samples of the cephalopod limestones from Algeria in 2005 and 2006.

\section{References}

BARRANDE, J. 1881. Systême silurien du centre de la Bohême. I ire partie: Recherches Paléontologiques, Classe des Mollusques, ordre des Acéphalés. 6.342 pp., 356 pls. Prague, Paris.

BogOLEPOVA, O.K. \& KŘÍŽ, J. 1995. Ancestral forms of Bohemian type Bivalvia from the lower Silurian of Siberia (Tungusskaja Syneclise, Russia). Geobios 28, 691-699. DOI 10.1016/S0016-6995(95)80062-X

GOLDFUSS, G. A. 1837. Petrefacta Germaniae - Abbildungen und Beschreibungen der Petrefacten Deutschlands und der angrenzenden Länder 6. Lieferung = Teil II, 3, 141-224.

KŘíž, J. 1969. Genus Butovicella Kříž, 1965 in the Silurian of Bohemia (Bivalvia). Sborník geologických věd, Palaeontologie 10, 105-139.

KŘíž, J. 1979. Silurian Cardiolidae (Bivalvia). Sborník geologických věd, Palaeontologie 22, 1-160, 40 pls.

KŘíž, J. 1996. Silurian Bivalvia of Bohemian type from the Montagne Noire and Mouthoumet Massif, France. Palaeontographica, Abt. 240, 29-63.

KŘíž, J. 1998. Recurrent Silurian-lowest Devonian cephalopod limestones of Gondwanan Europe and Perunica. In LANDING, E. \& Johnson, M.E. (eds) Silurian cycles: Linkages of $d y$ namic stratigraphy with atmospheric, oceanic, and tectonic changes. New York State Museum Bulletin 491, 183-198.

KŘíž, J. 1999. Silurian and lowermost Devonian bivalves of Bohemian type from the Carnic Alps. Abhandlungen der Geologischen Bundesanstalt 56, 259-316.

KŘíž, J. 2001. Enantiomorphous dimorphism in Silurian and Devonian bivalves; Maminka Barrande, 1881 (Lunulacardiidae, Silurian) - the oldest known example. Lethaia 34, 309-322. DOI 10.1080/002411601753293060 
KŘíž, J. 2007. Origin, evolution and classification of the new superorder Nepiomorphia (Mollusca, Bivalvia, Lower Paleozoic). Palaeontology 50(6), 1341-1365.

DOI 10.1111/j.1475-4983.2007.00720.x

KŘíž, J. \& BoGOLEPOVA, O.K. 1995. Cardiola signata Community (Bivalvia) in cephalopod limestones from Tajmyr (Gorstian, Silurian, Russia). Geobios 28(5), 573-583.

DOI 10.1016/S0016-6995(95)80212-6
LINNÉ, C. 1758. Systema naturae per regna tria naturae, secundum classes, ordines, genera, species, cum characteribus, differentiis, synonymis, locis. Editio Decima, reformata. 824 pp. Holmiae, Stockholm.

NEUMAYR, M. 1891. Beiträge zu einer morphologischen Eintheilung der Bivalven. Denkschriften der Kaiserlichen Akademie der Wissenschaften, Mathematisch-Naturwissenschaftliche Classe 58, 701-801. 